УДК 821.163.41.09

https://doi.org/10.18485/godisnjak.2018.13.5

\author{
Александра С. Секулић* \\ Институт за књижевност и уметност \\ Београд
}

Оригинални научни рад

Примљен: 14. 09. 2018.

Прихваћен: 15. 10. 2018.

\title{
МИЛОШ ЦРњАНСКИ И ДУШАН ВАСИЉЕВ: НИ ИСТО НИ ДРУКЧИЈЕ, АЛИ ОПЕТ ТО**
}

\begin{abstract}
Рад се бави односом Душана Васиљева према песничкој поетици Милоша Црњанског. Модернистички дискурс певања после рата у дијалогу који Васиљев води са Црњанским открива простор аутентичне интертекстуалне комуникације и поетичког самообликовања. Овај дијалог је утолико значајнији, уколико се одступи од интерпретатвног и критичког механизма налажења сличности који занемарује читав низ скривених конфликата, плодоносних мимоилажења.
\end{abstract}

Кључне речи: поетика, модернизам, рат, дијалог, Милош Црњански, Душан Васиљев.

Стваралачко настојање Душана Васиљева, његово поетичко хоћу из истоимене песме открива један изузетан сензибилитет, фигуру „песника рата" како је и назван новосадски зборник радова из 2015. године посвећен његовој поезији.

Хоћу да пођем бледом

мртваиу у рову,

и да се весео вратим;

да једним погледом све видике обухватим. (Васиљев 1932: 21)

*sekulic.aleks@gmail.com

${ }^{* *}$ Рад је настао у оквиру пројекта Смена поетичких парадигми у српској књижевности 20. века - национални и европски контекст (178016). 
Посебност у поезији Душана Васиљева не може оспорити ни његова снажна поетичка ослоњеност на Црњанског - Васиљевљев Пролог води експлицитан дијалог са Прологом из Лирике Итаке, веселост симболички кореспондира са невеселошћу Црњанског, чак и бледило којим је Дневник о Чарнојевићу направио неку врсту синестезијског омажа страдању на чијем се хоризонту слути руменост, упорност корала („Полинезија, господо!"), и бледило бледог мртваца се дакле, опире читању без овог јасног претекстуалног обриса. Уосталом, добар компаративни прилог о Црњанском и Васиљеву под насловом Повратак ратника дала је и Горана Раичевић (Раичевић 2015), доследно показујући фасцинацију Васиљева старијим песником која је присутна у „стиховима, идејама, метрици, па чак и структурној организацији песама тако да неке од њих звуче као намерне евокације Црњанскове лирике" (Раичевић 2015: 39). Ауторка у својој студији закључује и како се поезија Милоша Црњанског полако трансформисала у „поезију живота”, па макар то значило „и живот у нирванистичкој мирноћи суматраистичког субјекта", али да Васиљев у својим стиховима „није могао, или није стигао да црвенило крви претвори у црвенило корала и трешања" (Раичевић 2015: 45). Алудирајући на стихове Васиљевљевог Пролога и песму Жице, ауторка закључује како ће основна боја песника остати сива.

Ипак, када се констатује развијена интертекстуална мрежа на различитим поетичким нивоима, кад нешто већ звучи као „намерна евокација”, треба покушати, колико је год то могуће, са стрпљивим читањем оног аутентичног симболичког простора који настаје као плод дијалога. Васиљеву, иначе, нико не би опростио овај степен угледања, и био би књижевноисторијском и критичком силом осуђен на континуирани „час анатомије”. Овде ћемо узети само једну Васиљевљеву песму да покажемо како није све тако сиво, али и да назначимо основне поетичке валенце модернистичког певања после рата. Песмом Прошлост која није једини пример деликатних, амбивалентних и проблематизујућих нити унутар једног песничког дијалога, желимо да преиспитамо уврежене критичке ставове поводом Васиљевљевог односа према Црњанском.

Песма Прошлост има понешто наративизовану структуру и унутар ње смењивање укрштене и парне риме, с тим да, подељена у три групе стихова, делује као да садржи и извесне епизоде или, имитирајући Кјеркегора, рекли бисмо три стадијума - етички, поетички и митопоетски, уз њихово узајамно прожимање. (Овде ћемо их делити на мисаоне целине, зарад прегледности тумачења.)

По мосту што све за све сnаја,

прошао сам ходом меким, 
испуњен теретом сваког свог доживљаја у световима сањаним, далеким. ${ }^{1}$

Осим препознатљивог интонативно-мелодијског ткива, јасно се назиру песнички светови Милоша Црњанског. Видети у суматраизму мост „што све за све спаја”, иако сасвим логично и без неке неочекиване интерпретативне искре, у наредним стиховима показаће свој целовити симболички опсег. И меки ход као варијанта етеричне лакоће, безбрижног темпа космичке утехе, већ овде, на почетку, проблематизован је теретом песничког субјекта. У тим сањаним и далеким световима не олакшава се тежина доживљаја; првобитно, мучно искуство човека господари над његовом ирационалном и поетичком суштином.

И, место осећаjа,

који је свугде, у сваком кутку,

сриа што бије, -

на томе путу

није било светлости, сјаја.

Само је болна сета,

кљакава, сува, узета,

рамала горе-доле.

Колико је сјајна визија савладана болом и сетом, показује и предлог место као уместо; уместо светлости, космичке обасјаности постоји само пут који је негација, поништење далеких светова, метафизичког склоништа бића. Чак и да у предлогу видимо именицу место, то само појачава тоталитет слома који је немогуће поетички „излечити” - свако место је мрачно место, сваки „кутак срца” је то симболичко место безизлаза. И мост из првог стиха радикално је превреднован, јер по њему се само храмље „горе-доле”. Без преласка на другу страну, мост остаје пука конструкција или, још теже, остаје траг једног вишег, али туђег измирења, песничке имагинације и духовности која се унутар властите поезије не проналази.

Немогуће је, у певању Душана Васиљева, премостити сопствену сету која је, погледајмо атрибуте - кљакава, сува, узета, па још и није храмала него рамала ${ }^{2}$. С једне стране је приметна недвосмислена линија

\footnotetext{
${ }^{1}$ Сви наводи песме дати су према издању: Д. Васиљев, Изабране песме, Београд: СКЗ, 1932.

${ }^{2}$ Овде се отвара могућност за даљу филолошко-херменеутичку анализу наведеног глаголског облика. Чак и ако не можемо, са становишта фонологије, али и лексикологије, понудити један несумњиви и научно утемељени одговор, готово је извесно да би глас $x$ унеколико пореметио звучни, мелодијски низ асонанце. Из задњонепчаног х долази ваздушна струја која
} 
апропријације да тако кажемо, савременог наслеђа у Црњанском³ (ауто)поетички мазохизам: спрам лаког, меког хода суматраистичке благости одједном, сву симболичку превагу односе кљакавост и одузетост. Нема ружније и горе оцене преокрета у сопственој имагинацији која је међутим, сведочанство врхунске интертекстуалне размене. Јер, Васиљевљева сува сета (овде, нажалост, али само привремено, изостављамо анализу тактилне перцепције носталгије и меланхолије од Фукоа преко Сиорана до Еспена Хамера) постаје фрустрација истог трага, јаловог растојања од доле до горе, и обрнуто. Тако сува (бесплодна, празна, али парадоксално, увек самодовољна) одбија да пређе у светове који би је поетички разрешили, трансформисали. Кажемо одбија, јер целина песничког дела Душана Васиљева показује не да није могао или није стигао да пронађе сопствене корале и живот изван светскоисторијског терета (што показује песма из читанки Човек пева после рата, као и Плач Матере Човекове), већ да ће певати само тамо где су ужас и поетичко ужасавање, а нарочито што и у том ужасу има нечег ирвеног.

\author{
Осетио сам тада да није \\ прави циљь наш живот го, \\ препаднут \\ и разбојнички сатрвен. \\ И ако нам образ није ирвен, \\ увек морамо, ипак, знати то \\ да ћемо једном свега бити \\ до грла сити.
}

\begin{abstract}
чистом тону вокала ствара благу звучну препреку. Са друге стране, у низу деградација које читамо у наведеним стиховима, песнички субјект као да настоји и овим окрзнутим обликом да нагласи дубљу, симболичку немоћ и чак, естетску недостојност.

${ }^{3}$ Специфични однос Душана Васиљева према Милошу Црњанском представићемо још једном сликом, ризикујући да будемо и слободни у асоцијативном повезивању. Наиме, у једном интервјуу из седамдесетих година, на питање да ли му пишу читаоци, Црњански одговара како није добро појављивати се и превише излагати јавности: „Мени је добро било када су мене моји другови, кад сам био на Универзитету, волели као песника. То је мени било довољно". Духовито додавши, задовољан што му жена није ту па не може да га чује, и да су га колегинице волеле управо тако, као песника (Црњански 1992: 158). На страну колегинице, чак и Десанка Максимовић и Ружа Чајкановић које су, када је жандармерија једном приликом запуцала, стале испред Црњанског, на страну и уметничка транспозиција ове одбране коју ћемо читати у Хиперборејцима, када испред јунака стане његова „лепа и добра жена”. Овде нам је важан песник, песник Црњански јер га управо тако види и Душан Васиљев. Између фасцинације и фрустрације све је у поезији, све се догађа у дијалогу који није једини, али свакако спада међу књижевноуметнички транспарентније и драгоцене у српској књижевности 20. века. Иако, по свему судећи, Црњански Васиљеву одговара ћутањем.
\end{abstract}


Мада начин на који смо, из техничких разлога, поделили стихове, помало омета да се доживи њихова веза са претходним, али управо стихови који следе поткрепљују нашу тврдњу. Дакле, „осетио сам тада”, на тој путањи горе-доле, на путу страховите патње, а не у ескапизму и етеризму, „да није прави циљ” голи живот, „препаднут и разбојнички сатрвен”. Немоћан за „меки ход” метафизичке оријентације, Душан Васиљев циљ човековог живота песнички сагледава тек са искуством његовог беспоштедног укидања. И дијалог којим је начињен поетички избор мимо Црњанског, а сасвим унутар његове струје, дакле (само)опредељење и јединствени однос према савременику, према песнику са којим дели судбину ратника која је извесно стара, али и једну другу, евоцирану овим црвеним образом, до краја песме показаће своју пуну комплексност.

Образ је тако круцијално црвен у песми Прошлост, и то истиче сама модалност реченице колико и облик негације - И ако нам образ није ирвен. Све ће нам једног дана постати неподношљиво, сведочи песнички субјект, чак и да нам образ није црвен. Образ се црвени од стида или од љутње, од ударца свакако, нарочито ако је то симболички шамар (само)осуде, осећања кривице помешаног са кивном тугом. Интензитет и симболички значај овог црвенила на образу код Душана Васиљева поетички превасходи црвености корала. А то ће се нарочито видети у последњим стиховима песме, када се појаве и они други за које треба пасти на попришту. Из перспективе војника Првог светског рата, војника из Париза, Лондона и Берлина то је требало да буде само једна краткотрајна борба и зато су поносно марширали, са лицима која су била „слика задовољства” (Ferro 2002: 11) ${ }^{4}$. Али је такву слику врло брзо заменило искуство ратне катаклизме неслућених размера и сваки је војник, на крају, осетио узалудност своје жртве за лажне циљеве стварног механизма моћи. Када се, међутим, у песми Душана Васиљева, појави тај други за ког се гине, то више није тек симболичка сума бесмислене борбе за туђ рачун, већ и фрустрација ратовања за туђинца, за непријатеља. Ту где је образ црвен, чак и ако свима, без разлике, следује иста количина неподношљивости, Душан Васиљев прави наглашенији поетички искорак, скоро па песничку офанзиву, јер:

Стас поносити

не може нам донети среће,

а не може се крити ако смо унутра сасвим празни.

Да, не можемо, без бојазни

${ }^{4}$ „Године 1914. нису сумњали да би рат требало да буде кратак, да би, крунисани победом, требало да буду код куће око Божића. У Паризу, Лондону и Берлину одлазили су весели и певајући, 'са цвећем на пушкама"' (Ferro 2002: 11, превод наш). 
да ће нам се до краја огадити

голи животи -

скрштених руку чекати сутра.

Иронизацијом поноситог стаса Васиљев драстично мења тон, прелазећи у грубост и чак баналност, посебно ако се имају у виду фразеологизми у последњем стиху. Присутно је, међутим, и у оваквом букаџијском цинизму нешто што ипак песнички саопштава револт: јер, како би се уопште могло рачунати на срећу, у ма ком облику, ако је само важно умањити гађење које је неминовно. Претпостављена унутрашња празнина, уз ону суву сету и кљакави ход горе-доле, проширује симболички корпус немоћи, имагинацију самоповређивања. Јер, и у следећим стиховима, песник понавља историју свог мучног сазнајног пута и клонулости, након чега следи нова фаза поетичког преиспитивања:
И- бесомучна граја,
као око каквог ватреног загрљаја,
занела ми је ум.
И видех да сам преварен!
Јер није важно да ли је Ватра
оно ито све изгара,
или је ичиь наш Суматра.
И наша глава не може то да схвати,
зашто је најпреча Мати.

Капацитети различитих имагинација овом „смртно умореном”, али упорном песничком субјекту, што се даље одмиче искуством самопотраге, делују као „бесомучна граја”. Штавише, да је прошлост у песми Душана Васиљева ексклузивно и незаменљиво поетички присутна, показује и то што црвени образ и голи живот не могу да се рефундирају изван текста, као што не могу ни у тексту, али тек са властитом поетичком прошлошћу могуће је посумњати у Ватру и Суматру. Попут симболичког еха оног или-или код Црњанског ${ }^{5}$, Душан Васиљев, сада већ у етапи грозничаве рефлексије, опредељен је да бележи то што је и ђаво однео. Јер, наша глава не може то да схвати, чија је ово глава - је ли наша као глава свих нас песника, свих који смо после рата, никако послератни, већ управо тако, у предлошко-именичкој конструкцији која даје простора свој онтолошко-егзистенцијалној и најзад, поетичкој драми? Или смо то ми, међу којима има

${ }^{5}$ Али: или нам живот нешто ново носи, / а душа нам значи један степен више, / небу, што високо, звездано мирише, / ил нек и нас, и песме, и Итаку, / и све ђаво носи. (Црњански 1966: 14) 
само једна глава, виђена као наша? Та и таква, двосмислено припадајућа глава, не може да увиди значај мајке која је овде Мати, мада је, хронолошки гледано, првенствено била Матера. У већ споменутом тексту, Горана Раичевић каже како се идеја „доминантно индивидуалистичког нихилизма” Душана Васиљева, може везати за мисао аргентинског писца, Ернеста Сабата, који каже да „човек који није запамтио мајку, не може имати ни отаџбину” (Раичевић 2015: 47). Црњански је врло добро запамтио мајку, али је и тврдио да је завичај оно што изаберемо. Мајка Душана Васиљева поетички је већ афирмисана као контроверзна Матера, она плаче (и овде треба обратити пажњу на жанровску ревалоризацију) револуционарним плачем без суза. (Према отаџбини ће такође, имати изражен однос, амбивалентан али несумњив). Када се мајка Југовића надује и распадне, сузу не пустивши, у таквом чину живи епска имагинација „видовданске етике” мајчинства (Ђурић 1914: 69-71). Њена је савест, каже Милош Ђурић, „национално васпитачка”, те би сузе срозале узвишеност јуначке смрти, а њу представиле као мајку шмокљана, случајно пуштених од безбедних скута на бојно поље. Али, зашто би у српској књижевности 20. века, у песничком модернизму Душана Васиљева, била најважнија управо мати? ${ }^{6}$ При томе, тврдња да она јесте пре свега, најпреча, тако је формулисана да одаје утисак како ни сама не може апсолутно докучити симболички значај који заступа. Матера у модернизму Душана Васиљева плаче након што је сахранила и бога и сина, настанивши се поред гроба, стога је њена етика радикално измењена. Зато се ова Мати из песме Прошлост мора читати у контексту Матере и Мајке Марије, што је подтематски круг који овде нећемо отварати. Код Растка Петровића пак, матера је основа читаве једне материчне имагинације као поетички израженији продор у космолошку, пренаталну инспирацију модернизма. Након што исповеди ограничења душе, упркос свим њеним напорима, отвореним вратима и прозорима,

${ }^{6}$ Од Дневника о Чарнојевићу преко Љубави у Тоскани, Ламента над Београдом и Хиперборејаиа до Књиге о Микеланђелу, код Црњанског је фигура мајке заиста важна, у извесном смислу и „најпреча”, како би рекао Васиљев. О томе је и писано, али нам се чини, најмање са становишта аутентичне херменеутике Црњанског изражене у Хиперборејцима и у Књизи о Микеланђелу. Сви су врло брзо уочили психоаналитички дискурс, чији утицај на своја тумачења уосталом, ни сам Црњански не оспорава. Готово бисмо се могли кладити да ниједном студенту историје уметности није сугерисана Къига о Микеланђелу (Црњански је у интервјуима назива (ттудијом), али зато имају бескрајне спискове литературе која им фотографски преноси оно што и сами могу да виде, једино што ће савладати терминологију па пиластре неће назвати „као стубовима”, а за пронаос рећи да је предсобље. Исто тако, и студенту књижевности можда промиче читав један симболички комплекс читања и фигуре тумача у Хиперборејцима, који би се могао разматрати у распону од Доситеја до Црњанског. 
како каже песник, и закључи да ће „свака суштина увек остати непозната”, наставља се нови талас поетичког одмеравања:
Форма је силник, а садржина
сирота, мала Снежана.
Да, то је најважније,
да, да научимо хтети,
ма да нам живот како лети,
да у човеку себе познамо,
једно друго, лепше, боље себе.
И све да искрено дамо,
све што од нас и други нам ишту.
И још, ако треба, да на попришту
за те друге ми попадамо.

И Васиљев одбацује баласт форме, оне због које Црњански није марио за славу поетика, при чему, како каже професор Јерков, поетичка слобода ниче на згаришту једног света, а стихови Црњанског „постижу да је смисао њиховог облика истовремено и облик њиховог смисла" (Јерков 2010: 273). Али, додаје професор, само највећи могу постићи оно што постиже Црњански. Јер, свако се, угледавши ову „малу Снежану”, мора макар благо насмешити и бити затечен променом тона и стилског регистра.

Уосталом, ако бисмо и покушали да разрешимо ко или шта би могла бити ова Снежана, онда претпостављамо да нека нужност у имену постоји, иначе би избор могућих имена био несагледив ${ }^{7}$. Јер, за сада, ова мала Снежана делује као још један од реторичко-симболичких елемената нетрпељивости према самоме себи: песник преиспитује савремене облике певања и духовно-поетичких усмерења и, као да се, за разлику од Црњанског, не обрачунава са старим поетикама, већ је заокупљен оним што је те поетике увелико савладало, али у чему и даље не налази сопствену меру. Ако обратимо пажњу на стихове који претходе, Снежана би из перспективе оне која је најпреча, била управо име недостојности и духовног сиромаштва, као што је то најпрече у свакој форми изложено насиљу. Све ово нам и даље не одговара на питање одабира самог имена, мада, ако бисмо хтели да одемо сасвим предалеко - читано искључиво на хоризонту поетичког самеравања и песничког дијалога, Снежану бисмо могли ви-

\footnotetext{
${ }^{7}$ Драгана Вујаковић, ауторка студије о Душану Васиљеву под насловом Од крика до тишине: песништво Душана Васиљева између активистичког и апстрактног експресионизма, скоро да уопште не посвећује пажњу песми Проилост; интересантно је да, када управо наведене стихове спомене у посебном поглављу посвећеном формално-стилским и реторичким одликама Васиљевљеве поезије, ни тада се неће упустити у њихову подробнију анализу (Вујаковић 2009: 248).
} 
дети као покушај крајње негације суматраистичког дискурса у властитој поезији. Снег са Урала коначно је, за Душана Васиљева, мала Снежана, пародија сопственог певања тамо где би оно било једино празни одјек поезије Милоша Црњанског. Етичка димензија константно оспорава поетичку, и то је оно што Васиљева чини јединственом појавом у модернизму - између голог живота, егзистенцијалног ужаса и поетичке валоризације, Васиљев се и даље пита о ономе што је важно и најважније. А најважније је, каже песник, да научимо хтети, без обзира на живот, да „у човеку себе познамо". У човеку се дакле, мора пронаћи његова првобитност као човека, јер би то значило наду за сопство. Васиљев је управо песник код кога је брига о сопству најизраженија, нарочито, што њој претходи брига за вољу, вољу да се уопште буде човек. Читава филозофија двадесетог века покушала је да на изазов херменеутике субјекта пружи плаузибилне одговоре од Ничеа до Фукоа, а ако ли само кажемо „голи живот”, нико не може потиснути филозофску мисао Ђорђа Агамбена, иако тај рат као биополитички екстремизам, из перспективе Душана Васиљева, тек треба да се догоди. Јер, у поезији модернизма несумњиво постоји низ симболичких напетости између песничког субјекта и човека, између стварања и убијања. У песми Прошлост каже се да све своје треба искрено дати, „и још, ако треба, да на попришту за те друге ми попадамо". Приметићемо како је сваки траг песничког субјекта углавном дат у првом лицу једнине; песничко ја је индивидуално, оно само себе пева и певањем парадоксално, напушта прво лице. У напоредним токовима, покрет поетичке идентификације праћен је (да не кажемо оптерећен) етичким пробојима овог ми које додатно отежава поетичком ја да се конституише. Јер песник, не човек, осећа се превареним (бесомучном поетичком грајом), док ће ово ми захтевати искреност у борби за друге. Замислимо распон онтолошкопоетичке трауме која као да још једино у искреној погибији за сопственог џелата може писати „искрену песму”.

Шмит каже да политичка мржња није приватна и она нема никакве везе са субјективним односом према непријатељу. У човеку, пише Душан Васиљев, морамо познати ,једно друго, лепше боље себе”, и у том бољем ја налази се ова искреност умирања за непријатеље. Ни Шмит ни Дерида не кажу ништа о томе да само боља бића падају, попадавши за друге. Али је Дерида уз превод Политика пријатељства на српски језик написао предговор за српско издање под насловом Дар, податак, датуми. Дерида овде пише да читајући његову књигу, морамо осетити један „простор халуцинације", да мислимо предбудуће, аудитивно и визуелно, што је њему, на пример, омогућило да десет година раније, чује звук наших сирена за 
узбуну, хук бомби и зграда које се руше. Замишљам, каже Дерида, „нека читања ове књиге на вашем језику, кроз ваше историјско памћење, у дубини вашег политичког искуства” (Дерида 2001: 13). Замишљамо, ми који ово пишемо, Деридино читање песме Прошлост, њену филозофску халуцинацију на немогућем месту сусрета живота и литературе.

У последњем „стадијуму” песме окончава се један од плодотворнијих дијалога у поезији модернизма. Остале су само мисли „срамне, свргнуте”, које су свугде, како каже песник, пронашле место бола и слутњу да ће и човек и природа коначно завршити у власти ,злобног Хаоса”.
А он ће све звуке
у болне претворит' јауке,
и ко Хенил што просу
светлост обилно једне зоре -
све ће нас шчепати за косу
и баиит' у страшно, бурно море
својих тамних дубина...

На почетку и на крају стоји афирмација ужаса као пун круг прошлости, између је дуги пут поетичког понирања у етичке предиспозиције човека који пева после рата. И у последњим стиховима вибрирају могући трагови интертекстуалне дебате, која се овога пута међутим, неће аутоцинизмом окомити на властито певање. Јер, коса за коју ће нас, и песнике и оне који су спремни да искрено умиру за друге, шчепати зло злобног Хаоса, као да сугерише удаљавање и од стражиловске метафизике, где читамо: знам да ми у косу, / по зори руменотамној,/ туђа, уморна, рука, бледи сумрак просу (Црњански 1966: 76). Код Васиљева нема чак ни румености у зори, као што није било ни корално црвене, нема ни бледог сумрака, већ директне супституције светлости тамом.

Васиљевљев дијалог са Црњанским, као што смо то покушали да покажемо, упућује на улогу песничких самочитања и даље нас води до песника развијеног модернизма, да споменемо Растка Петровића и Станислава Винавера, који су својом поезијом стварали једну другачију „интерпретативну заједницу”. Нисмо желели да се задржимо на илустративном показивању утицаја, што је махом заступљено у критичком приступу српске науке о књижевности, по моделу који прво цитира стихове песника на кога се угледа, а потом стихове песника који се угледа. Поезија Милоша Црњанског и Душана Васиљева, њени имплицитни дијалошки, унутарпоетички сусрети и дистанце и експлицитни раскиди представљају симболичку нутрину година у којима је Европа крваво апострофирала распон геополитичких промена и стадијуме властите пропасти. Отуда су 
Црњански и Васиљев, као и други песници високог модернизма попут Растка Петровића и Винавера које смо само овом приликом изоставили, суштинске фигуре књижевне епохе у којој се „мишљење и певање”, као ратовање и певање, нашло у симболичкој спрези чији се поетички резултати и данас, и даље, морају још пажљивије испитивати.

\section{ЛИТЕРАТУРА}

Agamben 2011: Đ. Agamben, Homo sacer: Suverena moć i goli život, Loznica: Karpos.

Васиљев 1932: Д. Васиљев, Изабране песме, предговор В. Живојиновића, Београд: СКЗ.

Вујаковић 2009: Д. Вујаковић, Од крика до тишине: песништво Душана Васиљева између активистичког и апстрактног експресионизма, Нови Сад: Академска књига.

Дерида 2001: Ž. Derida, Politika prijateljstva, Beograd: Beogradski krug. Душан Васиљев песник рата, зборник радова, приређивач и уредник Јован Зивлак, Нови Сад: МБМ плас, 2015.

Јерков 2010: A. Jerkov, Smisao (srpskog) stiha. De/konstitucija, Beograd: Institut za književnost i umetnost.

Фepo 2002: M. Ferro, The Great War, London: Routledge Classics.

Црњански 1966: М. Црњански, Поезија, Београд: Просвета; Нови Сад: Матица Српска, Сарајево: Свјетлост.

Црњански 1992: M. Crnjanski, Ispunio sam svoju sudbinu, Beograd: BIGZ, SKZ, Narodna knjiga.

Aleksandra S. Sekulić

MILOŠ CRNJANSKI I DUŠAN VASILJEV: AGAIN, BUT NOT THE SAME

\section{Summary}

The paper deals with the relation of Dusan Vasiljev to the poetic of Miloš Crnjanski. The modernist discourse of singing after the war in the dialogue that Vasiljev leads with Crnjanski reveals the area of authentic intertextual communication and poetic "self-fashioning". This dialogue is all the more important, if it deviates from the interpretative and critical mechanism of finding a similarity that neglects a whole series of hidden conflicts, fruitful collisions.

Keywords: poetics, modernism, war, dialogue, Miloš Crnjanski, Dušan Vasiljev. 